\title{
Knowledge, Attitudes and Practices of Health Legislation and Regulations by Dentists and Stomatologists in the Valencian Community: A KAP Analysis.
}

Research Article

Keywords:

Posted Date: April 21st, 2021

DOI: https://doi.org/10.21203/rs.3.rs-294435/v2

License: (1) This work is licensed under a Creative Commons Attribution 4.0 International License.

Read Full License 


\section{Abstract}

The authors have requested that this preprint be withdrawn due to a need to make corrections. See https://doi.org/10.21203/rs.3.rs-208727/v2 for the updated version.

\section{Full Text}

The authors have withdrawn this preprint from Research Square. 